Canadian Journal of Plant Science Revue canadienne de phytotechnie

\title{
AAC Glenview Sainfoin (Onobrychis viciifoila subsp. viciifolia)
}

\begin{tabular}{|r|l|}
\hline Journal: & Canadian Journal of Plant Science \\
\hline Manuscript ID & CJPS-2017-0331.R2 \\
\hline Manuscript Type: & Cultivar description \\
\hline Date Submitted by the Author: & 07-Feb-2018 \\
\hline Complete List of Authors: & Acharya, Surya; AAFC, Lethbridge Research Centre \\
\hline Keywords: & sainfoin, New cultivar, bloat-free legume, Forage \\
\hline
\end{tabular}


CULTIVAR DESCRIPTION

\title{
AAC Glenview Sainfoin (Onobrychis viciifoila subsp. viciifolia)
}

\author{
S. N. Acharya \\ Agriculture and Agri-Food Canada, Lethbridge Research and Development Centre, \\ $5403-1^{\text {st }}$ Avenue South, Lethbridge, Alberta, Canada T1J 4B1.
}

\begin{abstract}
AAC Glenview sainfoin tested as LRC 4342 was developed by the Agriculture and Agri-Food Canada (AAFC) Research and Development Centre, Lethbridge, Alberta. This cultivar was derived from parental clones selected for improved forage yield in mixed stands with alfalfa under grazing and regrowth after grazing. When grown under irrigated and rainfed conditions of western Canada, Glenview out yielded Nova (check) by $21 \%$ in pure stands over 37 location years and $19 \%$ in mixed stands with alfalfa over 17 location years. This cultivar flowers and matures about 8 days earlier than Nova and has slightly larger seed than Nova (24.7 g 1000 seeds $^{-1}$ vs $\left.20 \mathrm{~g}\right)$. It can be grown for hay and pasture in pure stands but, Glenview is well suited for mixed sainfoin-alfalfa stands. Breeder seed for the cultivar will be produced by AAFC and the multiplication and distribution rights were awarded to Monarch Feeders Ltd., Monarch, AB.
\end{abstract}

Key words: Cultivar description, sainfoin, bloat-free forage legume Alfalfa (Medicago sativa) is considered the 'Queen of Forages' in western Canada because of its wide adaptation, productivity and ability to provide high quality forage. However, fear of pasture bloat limits its use in alfalfa-based pastures (Popp et al. 2000). In 
the past, numerous bloat control strategies have been developed, including the breeding of AC Grazeland alfalfa (Coulman et al. 2000) which is considered bloat-reduced not bloatsafe. Sainfoin (Onobrychis viciifolia), a high-tannin containing legume, is known to be bloat-safe. Bloat does not occur in sainfoin pastures or when fed fresh to cattle (McMahon at al. 1999; Berg et al. 2000). In addition, this condensed tannin containing legume prevents bloat in grazing cattle when present in alfalfa pasture in adequate proportion (Wang et al. 2006; Sottie et al. 2014). However, old sainfoin cultivars developed for western Canada such as Nova (Hanna 1980) do not persist in alfalfa stands and do not regrow at the same rate as alfalfa after cutting or grazing making the mixed stands risky to graze (Jefferson et al. 1994). To improve the ability of sainfoin to survive in mixed alfalfa stands and regrow at a similar rate as alfalfa the sainfoin improvement program at Lethbridge Research and Development Centre (LRDC) used a screening technique that included screening sainfoin both at the establishment and mature growth stages under a multiple cut/grazing system (Acharya et al. 2013). A number of new sainfoin populations, including the source population (LRC 3519) of Glenview (LRC 4342) were developed using a number of new source populations (Acharya et al. 2013). Since sainfoin is not subject to variety registration in Canada, a Certificate for Eligibility was obtained (Certificate No. 2040-2017 dated Dec. 18, 2017) from the Canadian Seed Growers' Association for AAC Glenview sainfoin.

\section{Origin and Breeding}

LRC 4342 is a 200 clone synthetic developed at the LRDC, Alberta. The parental clones were derived from crosses between selections developed from parental materials described in Table 1. 
The LRC 3519 sainfoin (the progenitor of LRC 4342) and AC Blue J alfalfa mixed pastures were established on June 19, 2008 for a replicated grazing trial at Lethbridge, AB. The trial was replicated four times. Each mixed pasture (paddock) was $4050 \mathrm{~m}^{2}$ and seeded with alfalfa and sainfoin in alternate rows with $18 \mathrm{~cm}$ row spacing using a $5 \mathrm{~m}$ wide no-till press-wheel type drill seeder (John Deere, Canada). Seeding rates were 5 and $15 \mathrm{~kg} \mathrm{ha}^{-1}$ pure live seed for alfalfa and sainfoin respectively, to achieve a 50:50 herbage density. Alfalfa and sainfoin seeds were inoculated using Dormal ${ }^{\circledR}$ (Becker Underwood, USA) and Royal Peat (Becker Underwood, Canada) inoculants respectively prior to seeding. At the time of seeding, $\mathrm{N}$ and $\mathrm{P}$ fertilizer was applied at the rate of 10 and $60 \mathrm{~kg}$ $\mathrm{ha}^{-1}$ respectively, to aid in pasture establishment. Perennial and grassy weeds were controlled using glyphosate (N-(phosphonomethyl) glycine) prior to seeding and annual weeds were controlled by mowing the crop twice during the establishment year. Residue was manually removed from the fields. After the establishment year the paddocks were rotationally grazed twice in each year for three years using steers at a stocking rate of 4.0 AUM ha ${ }^{-1}$ year $^{-1}$. In all years grazing was done between June and end of September with about a 35 day rest period. At the time of plant selection (fall 2011), the mean proportion of sainfoin in the pasture was $\sim 28 \%$. Selection criteria used was ability to survive in mixed alfalfa stands, rapid regrowth after grazing and high biomass productivity.

Six clones of each selected plants were grown in the greenhouse and in 2012, two clones of each selected plant were planted into a $20 \times 20$ breeding nursery at Lethbridge using 1 $\mathrm{m}$ spacing. Three such nurseries were planted under isolation (at least $200 \mathrm{~m}$ from any other sainfoin plots) to produce seed and to maximize chance for random intercrossing by 
native pollinators. After culling undesirable plants, seed from all three nurseries were bulk harvested and then combined in fall 2012 and designated as LRC 4342.

\section{Varietal Characteristics}

Growth habit: Erect growth, comparable to Nova.

Leaves: Dark green, multifoliate leaves with 25 lanceolate leaflets compared to 24 for Nova.

Stems: Stem height at $50 \%$ bloom is $92 \mathrm{~cm}$ vs 83 for Nova, $7 \mathrm{~mm}$ thick vs $5 \mathrm{~mm}$ for Nova, non-pubescent

Crown type: Medium crown width and depth

Roots: Similar to Nova, branched

Flower color: Same as Nova $100 \%$ pink, open pollinated

Flowering date: 37 days to flower compared to 45 for Nova

Regrowth: Rapid regrowth after cutting/grazing, very different from Nova

Pods: Round shape, pubescent, but matures about 8-10 days earlier than Nova

1000 Seed weight: $24.7 \mathrm{~g}$ with pod compared to $20 \mathrm{~g}$ for Nova

Winter hardiness: Same as Nova, No winterkill observed in western Canada over the past four years although stand decline under a multiple cut system is common

Disease reaction: Moderately susceptible to seed chalcid in storage 
Other agronomic characteristics: Tolerates grazing better than Nova, grows back after grazing in mixed stands with alfalfa and so can prevent bloat all summer. Nova does not grow back and so in mixed stands with alfalfa cannot prevent bloat all summer (see Table 5).

\section{Performance and Adaptation}

LRC 4342 is suitable for hay, dehydration and grazing in western Canada. This population is specifically suitable for mixed stand grazing with alfalfa in this region. AAC Glenview out yielded Nova up to $21 \%$ in pure stands and $19 \%$ in mixed stands with alfalfa (Tables 2 and 3). In western Canada the mean total annual dry matter yield of this cultivar under rain-fed conditions over 26 location years was $9.875 \mathrm{t} \mathrm{ha}^{-1}$, and $12.350 \mathrm{t} \mathrm{ha}^{-1}$ over 11 location years under irrigation (Table 2). In mixed stand with AC Blue J alfalfa, Glenview produced $11.94 \mathrm{t} \mathrm{ha}^{-1} \mathrm{DM}$ under rain-fed condition and $13.91 \mathrm{t} \mathrm{ha}^{-1}$ under irrigation (Table 3). In another test where performance of sainfoin cultivars were compared with alfalfa cultivars, Glenview performed better with AC Longview alfalfa than AC Blue J alfalfa, although the difference was not significant (Table 4).

Under irrigated conditions with Kayak orchardgrass, Glenview produced 26\% greater total dry matter than Nova sainfoin (Table 5). However, under rain-fed conditions mixed stand with orchardgrass, Glenview did not perform as well as Nova.

Over 4 location years seed production for Glenview sainfoin ranged from 600 to $1000 \mathrm{~kg}$ $\mathrm{ha}^{-1}$.

\section{Maintenance and Distribution of Pedigreed Seed}


Breeder seed of LRC 4342 will be maintained by Agriculture and Agri-Food Canada Research and Development Centre, Indian Head, Saskatchewan. Seed multiplication and distribution rights were given to Monarch Feeder Ltd., Monarch, AB.

\section{Acknowledgement}

The author gratefully acknowledges technical support provided by Doug Messenger and Doug Friebel, LRDC field crew and summer students who worked with the forage breeding group during the cultivar development and testing years. The cultivar development work was done using financial contributions from AAFC's Peer-review A-base Initiative. Financial contributions from ALMA and BCRC projects during the testing period are also acknowledged.

References:

Acharya, S.N. 2015. AAC Mountainview Sainfoin. Can. J. Plant Sci. 95: 603-607

Acharya, S. N., Friebel, D. R. and Castonguay, Y. 2005. Kayak orchardgrass. Can. J. Plant Sci. 87: 905-906.

Acharya, S.N. and Huang. H.C. 2000. AC Longview Alfalfa. Can. J. Plant Sci. 80: $613-615$

Acharya, S.N., Huang, H. C. and Hanna, M. R. 1995. AC Blue J alfalfa. Can. J. Plant Sci. 75: 469-471. 
Acharya, S., Sottie, E. Coulman, B., Iwaasa, A., McAllister, T., Wang, Y. and Liu. J. 2013. New sainfoin populations for bloat-free alfalfa pasture mixtures in western Canada. Crop Sci. 53:1-11.

Berg B.P., Majak W., McAllister T.A., Hall J.W., McCartney D., Coulman B.E., Goplen B.P., Acharya S.N., Tait R.M., and Cheng K.-J. 2000. Bloat in cattle grazing alfalfa cultivars selected for a low initial rate of digestion: A review. Can. J. Plant Sci. 80: 493-502.

Coulman B., Goplen B., Majak W., McAllister T., Cheng K.-J., Berg B., Hall J., McCartney D., and Acharya S.N. 2000. A review of the development of a bloatreduced alfalfa cultivar. Can. J. Plant Sci. 80:487-491.

Hanna, M.R. 1980. Nova sainfoin. Can. J. Plant Sci. 60: 1481-1483.

Jefferson, P. 1994. Evaluation of sainfoinalfalfa mixtures for forage production and compatibility at a semi-arid location in southern Saskatchewan. Can. J. Plant Sci. 74: $785+791$.

McMahon L.R., Majak W, McAllister T.A., Hall J.W., Jones G.A., Popp J.D., Cheng K. 1999. Effect of sainfoin on in-vitro digestion of fresh alfalfa and bloat in steers. Can J Anim Sci 79(2):203-212

Popp, J.D., McCaughey,W.P., Cohen, R.D. H.,McAllister, T.A. and Majak, W. 2000. Enhancing pasture productivity with alfalfa: A review. Can. J. Plant Sci. 80: $513 \_519$. 
Savatti, M., Ardelean, M. and Savatti Jr., M. 1994. Splendid a new sainfoin variety. Buletinul Universitatii de Stiinte Cluj Napoca Seria Agricultura si Horticultura. 1995. 48: 4145.

Wang, Y., Berg, B.P., Barbieri, L.R., Veira, D.M. and McAllister, T.A. 2006. Feed intake, ruminal fermentation, and development of bloat in steers grazing pastures of alfalfa or mixed alfalfa-sainfoin. Can. J. Anim. Sci. 86:383-392 
Table 1. Population designation, parentage, country of origin, selection method used and clonal composition of AAC Glenview (LRC 4342) sainfoin.

\begin{tabular}{|c|c|c|c|}
\hline $\begin{array}{l}\text { Population } \\
\text { designation }\end{array}$ & $\begin{array}{c}\text { Parent } \\
\text { population }\end{array}$ & Origin & $\begin{array}{l}\text { Selection method and number of selected } \\
\text { clones used }\end{array}$ \\
\hline LRC $3519^{*}$ & $\begin{array}{l}\text { Splendid } \\
\text { (Savatti et } \\
\text { al. 1994) }\end{array}$ & Romania & $\begin{array}{l}300 \text { individual plants selected after } 3 \text { spring } \\
\text { applications of } 1.0 \mathrm{~L} \mathrm{ha}^{-1} \text { of Cheminova } \\
\text { glysphosate } 356 \mathrm{~g} / \mathrm{L} \text { acid equivalent } \\
\text { (Cheminova Canada Inc.) were planted into a } \\
\text { nursery at Lethbridge, } \mathrm{AB} \text {. In Aug. } 2005 \text {, seed } \\
\text { from individual plants were harvested and } \\
\text { bulked. }\end{array}$ \\
\hline LRC 4342 & $\begin{array}{l}200 \text { clone } \\
\text { synthetic }\end{array}$ & $\begin{array}{l}\text { Alberta, } \\
\text { Canada }\end{array}$ & $\begin{array}{l}\text { LRC } 3519 \text { was seeded in alternate rows with } \\
\text { AC Blue J alfalfa for a grazing trial in } 2008 \text { at } \\
\text { Lethbridge, AB. The paddocks were } \\
\text { rotationally grazed by steers for three years } \\
\text { after establishment year. Clones of } 200 \text { plants } \\
\text { selected for their improved ability to survive } \\
\text { in mixed alfalfa stand, rapid regrowth under } \\
\text { grazing and biomass productivity were then } \\
\text { moved to three breeding nurseries for } \\
\text { intercrossing. Seeds from all three nurseries } \\
\text { were harvested in bulk and the resulting } \\
\text { population was named LRC } 4342 \text {. }\end{array}$ \\
\hline
\end{tabular}

Note: All populations and cultivars are Onobrychis viciifoila subsp. viciifolia. *The components of LRC 3519 were selected from nurseries $\left(30\right.$ X $\left.30 \mathrm{~m}^{2}\right)$ planted in rows with $1 \mathrm{~m}$ spacing. Clones from 200 selected plants were planted in 3 separate isolated breeding nurseries in Lethbridge from which seed was harvested in bulk. 
Table 2. Mean total yearly dry matter (DM) yield of AAC Glenview and Nova sainfoin in western Canada under rain-fed and irrigated conditions

\begin{tabular}{|lcccc|}
\hline Rain-fed & \# of Years & \multicolumn{3}{c|}{ Total DM Yield $\left(\mathrm{kg} \mathrm{ha}^{-1}\right)$ and \% check } \\
\cline { 3 - 5 } Locations* & (Trials) & Glenview & Nova & \% of Nova \\
\hline Creston & $7(3)$ & 14164 & 9842 & 144 \\
Foothills & $3(1)$ & 4457 & 3414 & 131 \\
Lethbridge & $9(3)$ & 10430 & 8690 & 120 \\
Melfort & $2(1)$ & 8222 & 8198 & 100 \\
Rosebank & $2(1)$ & 6512 & 7899 & 82 \\
Saskatoon & $3(1)$ & 6964 & 8065 & 120 \\
\hline Mean of 26 location years & 9875 & 8221 & \\
SE & & 1037 & 767 & 125 \\
& & & 75 \\
Irrigated & & & & 122 \\
Locations & & & & \\
\hline Lethbridge & $10(4)$ & 13216 & 10614 & 121 \\
Outlook & $1(1)$ & 3690 & 4905 & \\
\hline Mean of 11 location years & 12350 & 10125 & \\
SE & 413 & 527 & \\
\hline Mean of 37 location years & 10611 & 8787 & \\
SE & 760 & 549 & \\
\hline
\end{tabular}

*In Creston and Lethbridge plots were harvested three times per year. In Foothills, Melfort, Rosebank and Saskatoon the plots were harvested twice and once in Outlook. 
Table 3. Mean yearly total dry matter (DM) yield of AAC Glenview sainfoin and AC Blue J (BJ)* alfalfa mixed stands established at Creston, BC and Lethbridge, AB, under rain-fed and irrigated conditions

\begin{tabular}{|c|c|c|c|}
\hline \multirow[b]{2}{*}{$\begin{array}{l}\text { Rain-fed } \\
\text { Locations }\end{array}$} & \multicolumn{3}{|c|}{ Total DM Yield $\left(\mathrm{kg} \mathrm{ha}^{-1}\right)$ and $\%$ check } \\
\hline & Glenview/BJ & $\mathrm{Nova} / \mathrm{BJ}$ & $\begin{array}{c}\% \text { of } \\
\text { Nova/BJ }\end{array}$ \\
\hline Creston & 14077 & 11859 & 119 \\
\hline Lethbridge & 10073 & 8375 & 120 \\
\hline Mean of 10 location years & 11941 & 10014 & 119 \\
\hline SE & 642 & 555 & \\
\hline \multicolumn{4}{|l|}{ Irrigated Locations } \\
\hline Lethbridge & 13911 & 11687 & 119 \\
\hline Mean of 7 location years & 13911 & 11687 & 119 \\
\hline SE & 298 & 277 & \\
\hline Mean of 17 location years & 12729 & 10683 & 119 \\
\hline SE & 426 & 369 & \\
\hline
\end{tabular}

The plots were harvested three times a year and the mean yields represent total yield of all three cuts.

*Acharya et al. 1995 
Table 4. Mean yearly total dry matter (DM) yield of mixed sainfoin (Nova ${ }^{1}, \mathrm{AAC}$ Glenview and AAC Mountainview ${ }^{2}$ (MV)) and alfalfa (AC Blue $\mathbf{J}^{3}$ (BJ), AC Grazeland $^{4}$ (GL) and AC Longview ${ }^{5}$ (LV)) stands established in 2009 at Lethbridge, $A B$, under rain-fed conditions

\begin{tabular}{|ccccccccc|}
\hline & \multicolumn{9}{c}{ Total DM Yield (kg ha ${ }^{-1}$ ) } & & & \% \\
\cline { 2 - 7 } Mixtures & $\mathbf{2 0 1 1}$ & $\mathbf{2 0 1 2}$ & $\mathbf{2 0 1 3}$ & $\mathbf{2 0 1 4}$ & Mean & LSD & Nova/ LV \\
Nova/ LV & 10316 & 11543 & 12272 & 11626 & 11441 & df & 100 \\
Nova/ BJ & 9619 & 11831 & 11208 & 14317 & 11744 & df & 103 \\
Glenview/ LV & $\mathbf{1 2 6 4 2}$ & $\mathbf{1 3 7 5 5}$ & $\mathbf{1 4 8 8 7}$ & $\mathbf{1 5 1 7 6}$ & $\mathbf{1 4 1 1 5}$ & $\mathbf{a}$ & $\mathbf{1 2 3}$ \\
Glenview/ BJ & $\mathbf{1 2 2 9 6}$ & $\mathbf{1 2 4 1 6}$ & $\mathbf{1 4 0 4 7}$ & $\mathbf{1 5 4 3 3}$ & $\mathbf{1 3 5 4 8}$ & $\mathbf{a b c}$ & $\mathbf{1 1 8}$ \\
Glenview/ GL & $\mathbf{1 2 0 7 5}$ & $\mathbf{1 2 1 1 5}$ & $\mathbf{1 3 7 8 7}$ & $\mathbf{1 2 2 4 0}$ & $\mathbf{1 2 5 5 4}$ & bc & $\mathbf{1 1 0}$ \\
MV/ LV & 12382 & 12077 & 13139 & 14295 & 12973 & abc & 113 \\
MV/ BJ & 13023 & 12517 & 15024 & 14188 & 13688 & ab & 120 \\
MV/ GL & 11127 & 12411 & 13750 & 12375 & 12416 & c & 109 \\
\hline
\end{tabular}

This mixed stand experiment was seeded as in a RCBD with four replications and was harvested three times a year. The mean yields represent total biomass (sainfoin/alfalfa) of all three cuts. Sainfoin $\left(15 \mathrm{~kg} \mathrm{ha}^{-1}\right)$ and alfalfa $\left(5 \mathrm{~kg} \mathrm{ha}^{-1}\right)$ were seeded in alternate rows.

${ }^{1}$ Hanna 1980

${ }^{2}$ Acharya 2015

${ }^{3}$ Acharya et al. 1995

${ }^{4}$ Coulman et al. 2000

${ }^{5}$ Acharya and Huang 2000 
Table 5. Mean yearly total dry matter (DM) yield of Glenview and Nova sainfoin in mixed stands with Kayak* (KY) orchardgrass established at Lethbridge, AB, under rain-fed and irrigated conditions

\begin{tabular}{|c|c|c|c|}
\hline \multirow[b]{2}{*}{ Rainfed } & \multicolumn{3}{|c|}{ Total DM Yield $\left(\mathrm{kg} \mathrm{ha}^{-1}\right)$ and $\%$ check } \\
\hline & Glenview/KY & Nova/KY & $\begin{array}{c}\% \text { of } \\
\text { Nova/KY }\end{array}$ \\
\hline Lethbridge & 6745 & 7742 & 87 \\
\hline Mean of 3 location years & 6745 & 7742 & 87 \\
\hline SE & 712 & 1080 & \\
\hline \multicolumn{4}{|l|}{ Irrigated Locations } \\
\hline Lethbridge & 12235 & 9742 & 126 \\
\hline Mean of 3 location years & 12235 & 9742 & 126 \\
\hline SE & 413 & 750 & \\
\hline Mean of 6 location years & 9490 & 8742 & 109 \\
\hline SE & 916 & 695 & \\
\hline
\end{tabular}

*Acharya, S. N., Friebel, D. R. and Castonguay, Y. 2005. Kayak orchardgrass. Can. J. Plant Sci. 87: 905-906.

This mixed stand experiment was seeded as in a RCBD with four replications and was harvested two or three times a year under rainfed and irrigated conditions, respectively. The mean yields represent total biomass (sainfoin/orchardgrass) of all cuts. Sainfoin (15 $\left.\mathrm{kg} \mathrm{ha}{ }^{-1}\right)$ and Kayak orchardgrass $\left(3 \mathrm{~kg} \mathrm{ha}^{-1}\right)$ were seeded in alternate rows. 